\title{
Pharmacognostical evaluation and anti-convulsant property of Annona reticulata Linn. (Annonaceae) root
}

\author{
S. Manoj Kumar ${ }^{1}$, Mohammad Azamthulla ${ }^{2}$ and Kamatchi Sundara Saravanan ${ }^{1 *}$ (i)
}

\begin{abstract}
Background: The present investigation was aimed at establishing the pharmacognostical parameters and preliminary phytochemical screening of Annona reticulata Linn. (Annonaceae) root. Pharmacognostical studies and phytochemical evaluation of $A$. reticulata root were carried out by following standard procedures to provide information that help to identify the species. The species of Annonaceae family are documented to possess anticonvulsant property, while A. reticulata and its root are reported to be used as a folklore medicine to treat epilepsy. In this study, anti-convulsant activity of the root extract was further investigated in mouse model with seizures induced by pentylenetetrazole (PTZ; $60 \mathrm{mg} / \mathrm{kg}$, i.p.). Diazepam ( $5 \mathrm{mg} / \mathrm{kg}$ ) was used as a standard anti-convulsant drug. Prior to induction of seizures, ethanol extract (100, 200, and $400 \mathrm{mg} / \mathrm{kg}$, P.o.,) and $0.1 \%$ sodium CMC were administered. Later, the onset, duration of convulsions along with recovery was recorded.

Results: A. reticulata can be recognized by its crown shape, leaves with lengthy petioles, fleshy petals and heartshaped fruits. Roots are cylindrical with rootlets and have aromatic odour. Presence of oil globules and rhomboidal calcium oxalate crystals in cortex, sclerenchyma cells in cortex and secondary phloem, starch grains in cortex, secondary phloem and secondary xylem, and uni- to tri-seriate medullary rays are the key diagnostic characters of root. Preliminary phytochemical screening of extracts revealed the presence of phenolic compounds, tannins, alkaloids, carbohydrates, flavonoids, glycosides, saponins, proteins, fixed oil and fats. The total alkaloid content in the root was $0.524 \% \mathrm{w} / \mathrm{W}$, while total flavonoid and total phenolic content in ethanol extract were $16.65 \mathrm{mg}$ QE/g and $59.54 \mathrm{mg}$ $\mathrm{GAE} / \mathrm{g}$, respectively. Based on the values obtained from anti-convulsant activity, it is evident that the ethanol extract offered significant protection against PTZ-induced convulsion in mice.

Conclusion: The current pharmacognostical study aids not only in identification of crude drug material but also in establishing the standardization parameters. Further, the findings of this study indicated that the ethanolic extract of Annona reticulata Linn root displayed significant anti-convulsant property and this property could be attributed to imperative bioactives like flavonoids, phenolic compounds, alkaloids, in addition to other secondary metabolites.
\end{abstract}

Keywords: Annona reticulata, Pharmacognosy, Anti-convulsant, Pentylenetetrazole

\footnotetext{
*Correspondence: sundarksharan@gmail.com

${ }^{1}$ Department of Pharmacognosy, Faculty of Pharmacy, M. S. Ramaiah

University of Applied Sciences, Bangalore, Karnataka 560 054, India

Full list of author information is available at the end of the article
} 


\section{Background}

Epilepsy, a neurological disorder discerned by transient bouts of abnormal excessive and synchronous electrical activity in brain, is associated with various neurobiological, cognitive, psychological signs and symptoms [1]. The management of epilepsy involves usage of diverse category of drugs such as benzodiazepines, barbiturates, gamma aminobutyric acid (GABA) analogs, hydantoins, carbamazepine, etc. [2]. Already existing anti-epileptic drugs were considered to exhibit better efficacy and safety profile. However, these drugs possess one/more inherent adverse effects such as ataxia, dizziness, impaired concentration, sleep disturbance, anorexia, and aggression [3]. Hence, there is immense scope for developing potent and safe drugs for effective treatment of epilepsy.

Herbs with medicinal properties are the oldest accredited health care products used by individuals across the globe. These herbs constitute a major part of the classical formulations prescribed by any of the traditional systems of medicine and/or folk medicines practiced throughout the country $[4,5]$, and they have been the source of therapeutic agents for years together. Despite the huge advancements brought about in the formulation and development of allopathic medicines, even today $60-80 \%$ of population belonging to developing countries still consider herbal medicines to be safe and economic. Moreover, an extensive usage of plant-based remedies as complementary health care has also been documented in developed countries [5]. Ancient knowledge in natural products as source of remedies is being used as an approach in treating various ailments. Awareness and understanding of primordial information on plants led to the exploration of their potential use, and to provide scientific data through research.

The family Annonaceae comprises trees or shrubs often climbing, frequently aromatic and includes various genus, viz. Sagerarea, Uvaria, Cyathocalyx, Artabotrys, Unona, Polyalthia, Popowia, Phaenthus, Goniathalamus, Mitrephora, Annona, Xylopia, Miliusa, Saccopetalum, Alphonsea and Orophea [6]. Traditionally, the species of this family are used as astringent, analgesic and in various conditions like convulsions, diarrhoea, dysentery, rheumatoid pain, neuralgia, etc., [7, 8]. Annona Linn. one among the genus of Annonaceae is reported to possess number of species, out of which A. squamosa Linn. and A. reticulata Linn. are distributed in India [6]. The information on traditional applications of $A$. reticulata reveals its use in the treatment of epilepsy, constipation, haemorrhage, cardiac problems, dysentery, worm infestation, bacterial infection, dysuria, etc. $[9,10]$.

This plant contains diverse class of compounds that includes alkaloids, tannins, phenols, flavonoids, glycosides, and steroids. The important constituents of root bark include anonaine, liriodenine, oxoushinsunine, reticuline, while stem bark contains anonaine, oxoushinsunine, reticuline, michelalbine, asimilobine, annomontine, acetogenins, etc. Leaves possess elemol, $\alpha$-eudesmol, $\alpha$-cadinol, etc., and seed contains fatty oil and $\mathrm{N}$-fatty acyl tryptamines [10,11].

Various reports pertinent to this plant suggested its significant antipyretic, anthelmintic, antihyperglycemic, antiulcer, antinociceptive, analgesic, CNS depressant, anti-inflammatory, wound healing, antimarking, antioxidant, antimicrobial activity, etc., [10, 12], while root is reported for antiproliferative [13], cytotoxicity [14], antioxidant, antimicrobial [15], anthelmintic [16], antiplasmodial [17], and larvicidal [18] activity.

Nowadays researches are focused towards herbal therapies to ascertain safe and better remedy for epilepsy, as drugs of natural origin are considered to possess better edge over synthetically derived compounds. The present study was undertaken with an aim to establish the root pharmacognostical parameters and phytochemical profiles that aids in correct identification of the species, besides evaluating its potential anti-convulsant property.

\section{Methods}

\section{Collection and authentication of plant material}

Root material was collected from Sadahalli village, Devanahalli Taluk, Bangalore, Karnataka, India during July, 2019. Few fresh pieces of root material were stored in $70 \%$ alcohol for macro- and microscopical studies. A herbarium was prepared [19] following curatorial practices and deposited along with crude drug material for future reference (UASB-4602).

\section{Pharmacognostical studies}

Macroscopical studies were performed on the intact root material collected, while microscopical evaluation was carried out on thin free hand transverse sections. Macerate was prepared by treating small cut pieces of root with $50 \% \mathrm{HNO}_{3}$ along with little quantity of $\mathrm{KClO}_{3}$ and boiled until brown fumes were observed. Then, it was washed with distilled water thoroughly to obtain acid-free material. The transverse sections, macerate elements and powdered material were treated with various reagents like phloroglucinol:conc. $\mathrm{HCl}(1: 1)$, safranin, iodine solution and examined under compound binocular microscope. Later, cells, tissues in section and macerate were measured. Histochemical tests were also performed by treating thin transverse sections with various test reagents like phloroglucinol and conc. $\mathrm{HCl}$, millon's reagent, iodine, sudan III, ferric chloride and ruthenium red solution to identify cell contents [20,21]. 


\section{Phytochemical studies}

The physico-chemical constants, viz., loss on drying, yield to water and alcohol (95\%), ash values (total, acid insoluble, water soluble), were determined. Ultraviolet analysis was performed by treating powder sample with various reagents, and observations were made under visible, $254 \mathrm{~nm}$ and $365 \mathrm{~nm}$. Successive solvent extraction was carried out using sequence of solvents with increase in polarity, and the obtained extracts were tested for the presence of various phytochemicals [22-24].

\section{Total alkaloid content}

The method outlined by Rinaldi et al.[25] was followed to determine the total alkaloid content. Coarsely powdered root was extracted thrice with $0.1 \mathrm{M}$ phosphoric acid under agitation for $1 \mathrm{~h}$. Then the acid solution was partitioned with hexane and $\mathrm{pH}$ adjusted to 9 with $25 \%$ ammonium hydroxide. The $\mathrm{pH}$ adjusted solution was extracted with chloroform in a separating funnel until the extract showed negative for alkaloids with Dragendorrf's reagent. The chloroform layer was then dried with anhydrous sodium sulphate and concentrated to determine the total alkaloid content.

\section{Total phenolic content}

Total phenolic content was calculated using Folin Ciocalteau reagent, and absorbance was measured in UV-visible spectrophotometer (Shimadzu UV-1700). One ml of total ethanol extract and various dilutions of standard gallic acid were separately taken in a $10-\mathrm{ml}$ volumetric flask. To each of the flask, distilled water $(5 \mathrm{ml})$ and Folin Ciocalteu's reagent $(0.5 \mathrm{ml})$ were added. After $5 \mathrm{~min}, 20 \%$ sodium carbonate solution $(1.5 \mathrm{ml})$ was added, made up to $10 \mathrm{ml}$ with ethanol and incubated for $2 \mathrm{~h}$. The absorbance of the developed intense blue colour was measured at $750 \mathrm{~nm}$ and the total phenolics present in the extract was calculated and represented as gallic acid equivalent (GAE) [26].

\section{Total flavonoid content}

Total flavonoid content was estimated using aluminium chloride assay. One $\mathrm{ml}$ of sample and standard (quercetin) were separately taken in a $10-\mathrm{ml}$ volumetric flask. Distilled water $(4 \mathrm{ml})$ and sodium nitrate $(5 \%, 0.3 \mathrm{ml})$ were added to each flask. After $5 \mathrm{~min}$, aluminium chloride $(0.3 \mathrm{ml} ; 10 \%)$ was added followed by $\mathrm{NaOH}(2 \mathrm{ml}$, $1 \mathrm{M})$ and made up to $10 \mathrm{ml}$ with ethanol. The absorbance of developed orange yellow colour was measured at $510 \mathrm{~nm}$ in Shimadzu UV-1700 spectrophotometer. The total flavonoid was calculated and represented as Quercetin equivalent (QE) [26].

\section{Pharmacological activity studies \\ Chemicals/drugs}

Pentylenetetrazole and sodium CMC were obtained from Hi Media, while Diazepam was from Ranbaxy Laboratories Ltd.

\section{Animals}

The study protocol was approved by Institutional Animal Ethics Committee and conducted by following CPCSEA guidelines strictly, India. Swiss Albino mice of 10 weeks old were used for establishing the pharmacological activity pertinent to $A$. reticulata root. The animals of either sex in the weight range of 25-30 g were included in the study, while the animals less than $25 \mathrm{~g}$ and more than $30 \mathrm{~g}$, pregnant animals and lactating animals were excluded. The selected animals were kept under quarantine in a clean environment for a period of two weeks in animal house facility $\left(25^{\circ} \mathrm{C} \pm 1{ }^{\circ} \mathrm{C}\right)$ of the faculty and maintained in polypropylene cages under $12 \mathrm{~h}$ light/dark cycle. During this period, the animals had water ad libitum and standard pellet diet.

\section{Acute toxicity study}

Acute toxicity study of ethanol extract was carried out by following Organization for Economic Co-operation and Development (OECD) 423 guidelines [27]. Initially, animals were fasted overnight prior to dosing with water ad libitum. Extract concentration for administration was prepared in such a way that the volume does not exceed $1 \mathrm{ml} / 100 \mathrm{gm}$ body weight of mice. Three female Swiss albino mice in the weight range of $25-30 \mathrm{~g}$ were administered with a dose of $2000 \mathrm{mg} / \mathrm{kg}$ suspended in $0.1 \%$ Sodium CMC. After administration, each animal was kept under observation for the first $24 \mathrm{~h}$, with subsequent observations once daily were recorded for next consecutive 14 days for the development of abnormality and/or mortality.

\section{Anti-convulsant activity Pentylenetetrazole (PTZ) induced convulsion}

A total of 30 Swiss albino mice of either sex in the weight range of 25-30 g were divided randomly into five groups with six animals in each group $(n=6)$. Group I-Control group received vehicle ( $1 \mathrm{ml} 0.1 \%$ Sodium CMC), Group II-Standard group received diazepam (5 mg/kg, i.p.,), Group III-Low-dose-extract-treated group received 100, Group IV-Moderate-dose-extract-treated group received 200, and Group V-High-dose-extract-treated group received $400 \mathrm{mg} / \mathrm{kg}$ of ethanol extract. Groups I, III, IV and V were intraperitoneally administered with 


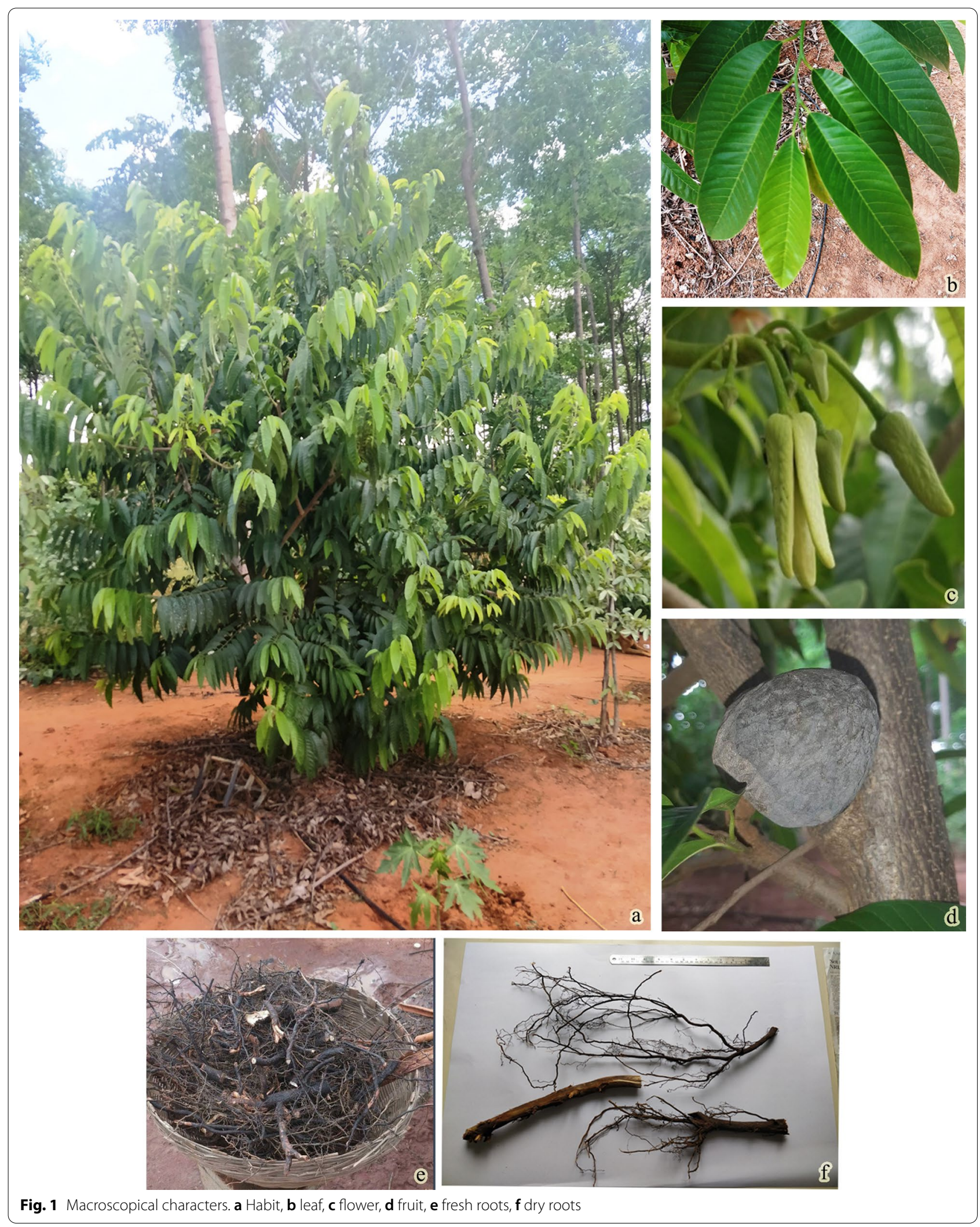


PTZ $(60 \mathrm{mg} / \mathrm{kg})$ after one hour of vehicle and extract treatment, while Group II was administered with PTZ $(60 \mathrm{mg} / \mathrm{kg})$ after $30 \mathrm{~min}$ of standard drug treatment. After PTZ administration, the following parameters such as jerks, straub's tail and death or survival were monitored and recorded. The latency of onset of convulsion and time taken for recovery were also noted $[28,29]$. The data obtained from all the treated groups were compared with control group. After the completion of the study, the animals were euthanized by decapitation method.

\section{Statistical analysis}

The results obtained in the study were statistically analysed by one-way analysis of variance (ANOVA) followed by Tukey's Kramer multiple comparison tests. All the values were expressed as Mean \pm Standard Error of Mean $(n=6)$. Statistical analysis was carried out using GraphPad InStat V-3 software.

\section{Results}

\section{Pharmacognostical studies}

\section{Habit and habitat of A. reticulata}

Annona reticulata thrives abundantly well in tropical region under humid climatic conditions with enough water supply and sunlight. Trees are small, with branches being tomentose when young and glabrous as they mature. Leaves are petiolate, oblong-lanceolate, around 10-15 cm long, 3-6 cm wide, with acute/obtuse apex and cuneate/ round base. Petiole is around 1-2 cm in length. Flowers are $2-4$, on lateral pedicels. Pedicels are around $1-2 \mathrm{~cm}$ in length. Fruits are heart shaped or sub-globose with rough outer surface, yellowish-red or yellow inner side as it ripens and contains numerous hard seeds (Fig. 1a-d).

\section{Macroscopical characters}

The roots collected are stout, fibrous with numerous secondary rootlets, cylindrical and measure up to $6 \mathrm{~cm}$ in diameter. Dried roots are fibrous, hard with thin brown bark and large yellow wood. Root fracture is fibrous and possesses mild sweet taste with aromatic odour (Fig. 1e, f).

\section{Microscopical characters}

Transverse section of the root exhibits a circular outline. The outer surface shows rhytidome, followed by a narrow cork, cortex, secondary phloem and a wide secondary xylem region. Cork is made up of 7-10 layers of tangentially elongated tabular parenchyma arranged in radial rows measuring 6.28-15.03-23.18 × 2.81-5.75-7.56 $\mu \mathrm{m}$. The cortex is composed of multilayered parenchyma cells measuring 11.78-16.0-22.75 × 3.59-9.58-13.75 $\mu \mathrm{m}$. Oil globules $(3.30-5.87-8.74 \mu \mathrm{m})$, calcium oxalate crystals of rhomboidal shape and occasional groups of scattered lignified stone cells $(2.81-4.30-6.56 \mu \mathrm{m})$ are observed in cortical region. A narrow secondary phloem next to cortex characterized by thin-walled cells interlaced with groups of lignified sclerenchyma and medullary rays is seen. Next to secondary phloem is a broad secondary xylem composed of medullary rays, vessels and parenchyma. Medullary rays are predominantly uni- to tri-seriate measuring 6.67-10.99-15.88 × 3.98-5.59-7.43 $\mu \mathrm{m}$, while the vessels are oval to spherical in shape and measure 5.89-13.82-39.02 × 3.57-10.27-45.44 $\mu \mathrm{m}$. The medullary ray in secondary phloem is broad, while it narrows down in the secondary xylem region. Starch grains of spherical shape measuring 2.05-5.34-10.52 $\mu \mathrm{m}$ were observed in medullary ray parenchyma and xylem parenchyma as well (Fig. 2a1-a7).

\section{Macerate characters}

Macerate studies displayed the following elements: Thin-walled parenchyma cells (11.27-15.53$28.03 \times 5.41-7.84-12.58 \mu \mathrm{m})$, pitted parenchyma $(9.59-26.30-69.69 \times 5.39-10.93-22.80 \mu \mathrm{m})$, reticulate parenchyma (15.04-23.71-47.93 × 3.72-9.23-18.58 $\mu \mathrm{m})$, vessels with different sizes and shapes, with pitted type of thickenings, sub-terminal openings, drawn out ends measuring 42.84-78.47-178.75 ×9.27-22.06-72.23 $\mu \mathrm{m}$ and fibres with variable wall thickness, lumen and ends $\quad(161.97-348.86-718.97 \times 2.72-9.07-17.05 \mu \mathrm{m})$ (Fig. 2a8-a18).

\section{Powder characters}

Powder showed fragments of cork cells, groups of lignified sclerenchyma cells, medullary ray cells accompanying xylem elements; spindle-shaped lignified fibres, parenchyma containing starch grains, starch grains of simple and compound type with spherical shape, lignified pitted parenchyma, fragments of vessels with pitted

\footnotetext{
(See figure on next page.)

Fig. 2 a 1-a7 Microscopical characters of root, a8-a18 Macerate characters, a19-a31 Powder characters. a1 Transverse section showing cork, cortex, secondary phloem and secondary xylem, a2 enlarged cork, a3 cortex with oil globule, a4 cortex and secondary phloem with oil globule and sclerenchyma cells, a5 secondary xylem showing vessels and medulary rays, a6 medulary ray cells and parenchyma with starch grains, a7 cortex showing crystal, a8 parenchyma, a9 reticulate parenchyma, a10 pitted parenchyma, a11-a16 vessels, a17-a18 Fibres, a19 Parenchyma, a20a21 Sclerenchyma cells, a22 medulary ray cells, a23 fibres, a24-a25 starch grains, a26 Wood elements, a27 pitted parenchyma, a28 Reticulate PARENCHYMA, a29-a30 fragments of vessels, a31 crystal
} 


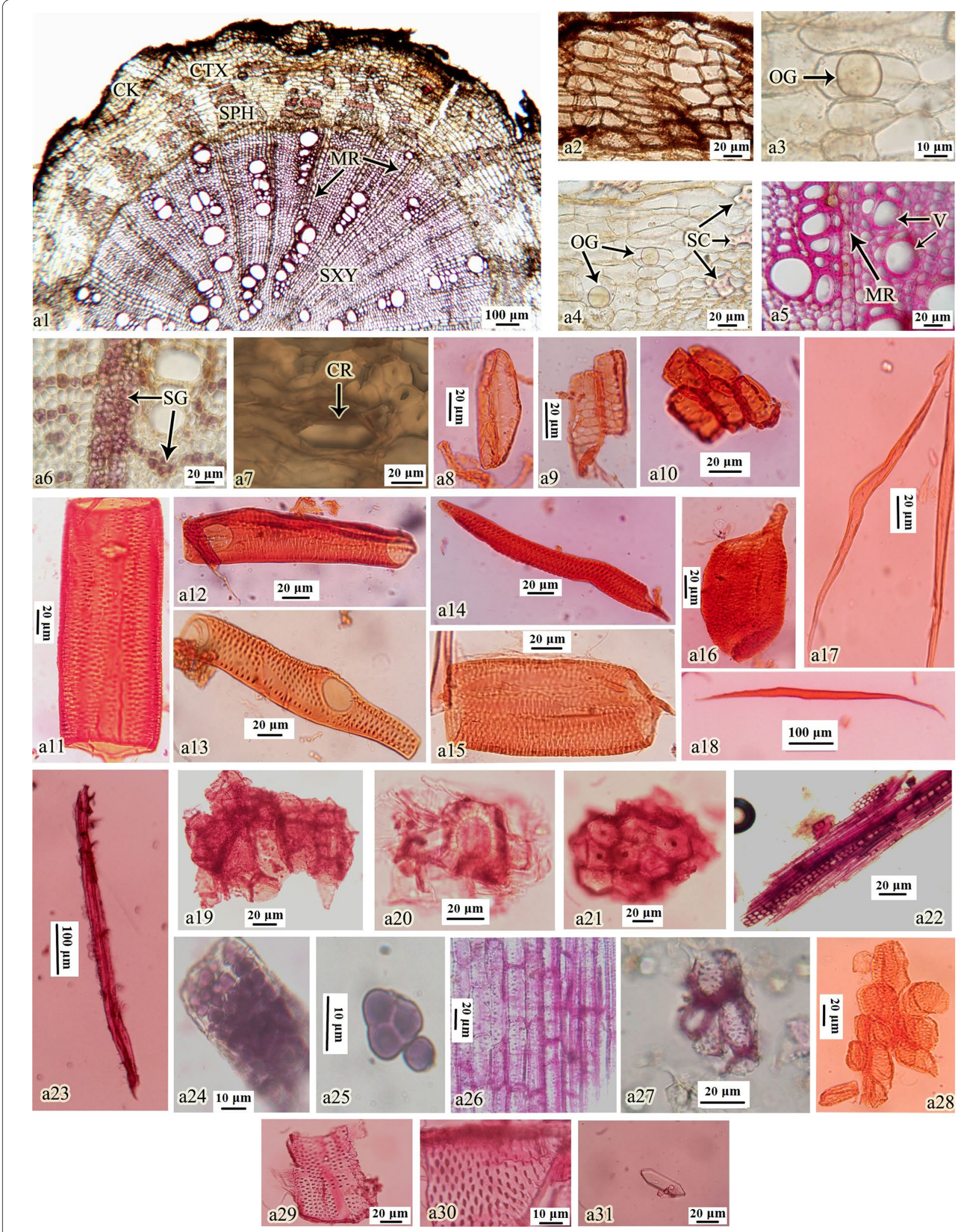

Fig. 2 (See legend on previous page.) 
Table 1 physico-chemical constants of A. reticulata root powder

\begin{tabular}{lllllll}
\hline $\begin{array}{l}\text { Loss on } \\
\text { drying }(\% \\
\text { w/w) }\end{array}$ & \multicolumn{2}{l}{ Ash value $(\% \mathrm{w} / \mathrm{w})$} & & \multicolumn{2}{l}{$\begin{array}{l}\text { Extractive value }(\% \\
\mathrm{w} / \mathrm{w})\end{array}$} \\
\cline { 2 - 4 } & Total & $\begin{array}{l}\text { Acid } \\
\text { insoluble }\end{array}$ & $\begin{array}{l}\text { Water } \\
\text { soluble }\end{array}$ & & $\begin{array}{l}\text { Water } \\
\text { soluble }\end{array}$ & $\begin{array}{l}\text { Alcohol } \\
\text { soluble }\end{array}$ \\
\hline 12.63 & 5.80 & 1.99 & 0.93 & & 6.70 & 8.76 \\
\hline
\end{tabular}

Table 2 Successive solvent extraction of $A$. reticulata root powder

\begin{tabular}{llll}
\hline Solvent & Color & Consistency & $\begin{array}{l}\text { Extractive } \\
\text { value } \\
\text { (\%w/w) }\end{array}$ \\
\hline n-hexane & Dark green & Sticky mass & 4.72 \\
Toluene & Brown & Solid & 2.38 \\
Chloroform & Brown & Solid & 1.22 \\
Ethyl acetate & Brownish green & Solid & 1.37 \\
Ethanol & Reddish brown & Solid & 8.67 \\
Water & Brown & Solid & 4.87 \\
\hline
\end{tabular}

thickenings, and rhomboidal calcium oxalate crystals (Fig. 2a19-a31).

\section{Histochemical studies}

Thin root sections revealed the presence of lignin (pink with phloroglucinol and conc. $\mathrm{HCl}$ ), starch (blue with iodine solution), protein (red with millon's reagent), lipids (red with sudan III), tannins (bluish black with $\mathrm{FeCl}_{3}$ ) and absence of mucilage (no pink with ruthenium red solution).

\section{Physico-chemical constants}

The physico-chemical constants (loss on drying, ash values, extractive values) determined are reported in Table 1 . The colour, consistency and percentage yield of root powder to various solvents are displayed in Table 2 .

\section{Fluorescence analysis}

The characteristic color exhibited by root powder under visible and UV ( 254 and $365 \mathrm{~nm}$ ) radiation upon treatment with various solvents/reagents is tabulated in Table 3.

\section{Preliminary phytochemical screening}

Preliminary phytochemical analysis of extracts obtained through successive solvent extraction revealed the presence of alkaloids, phenolic compounds and tannins, saponins, flavonoids, glycosides, carbohydrates, proteins, fixed oil and fats. Volatile oil from the dried root was found to be $0.2 \% \mathrm{v} / \mathrm{w}$ by hydrodistillation.

\section{Total alkaloid, total flavonoid and total phenolic content}

The total alkaloid content in root powder was $0.524 \%$ $\mathrm{w} / \mathrm{w}$, while the total phenolic and total flavonoid content of ethanol extract were found to be $59.54 \mathrm{mg} \mathrm{GAE} / \mathrm{g}$ and $16.65 \mathrm{mg} \mathrm{QE} / \mathrm{g}$, respectively.

\section{Pharmacological activity studies Acute toxicity study}

Acute toxicity evaluation on experimental animals administered with $2000 \mathrm{mg} / \mathrm{kg}$ dose of ethanol extract did not show any signs of toxicity during short-term ( $24 \mathrm{~h}$ ) and long-term (14 days) observation period. Therefore, three doses, $1 / 20$ th $(100 \mathrm{mg} / \mathrm{kg}$, low dose $), 1 / 10$ th (200 mg/kg, mid dose) and 1/5th (400 mg/kg, high dose)

Table 3 Fluorescence analysis of A. reticulata root powder

\begin{tabular}{llll}
\hline Reagents & Visible light & Ultraviolet light & Long wave (365 nm) \\
\cline { 3 - 4 } & & Short wave (254 nm) & Light biscuit- $N$ \\
\hline Powder as such & Sand stone & Sands of time & Maroon \\
$50 \% \mathrm{H}_{2} \mathrm{SO}_{4}$ & Coffee & Pine & Revel \\
$50 \% \mathrm{HNO}_{3}$ & Old brick & Meadow path & Milan red \\
$5 \% \mathrm{KOH}$ & Terracotta & Amazon moss & Meadow path \\
Methanol & Autumn gold & Vivid green & Amazon moss \\
Ethanol & Vintage walnut & Mehendi-N & Armada \\
In Acetone & Moody maroon & Green gold & Autumn gold \\
$1 \mathrm{~N} \mathrm{HCL}$ & Nut-brown-N & Pine-N & Moghul green \\
$1 \mathrm{~N} \mathrm{Methanolic} \mathrm{NaOH}$ & Honey comb & Moghul green & Nut Brown \\
$1 \mathrm{~N} \mathrm{Ethanolic} \mathrm{NaOH}$ & Vintage walnut & Dark drama & Ming red \\
Powder + dil $\mathrm{NH} H_{3}$ & Moody maroon & Vivid green &
\end{tabular}

All color comparison is based on the "Asian paints" premium gloss enamel card. Asian paints limited, Mumbai 
Table 4 Effect of ethanol extract of A. reticulata root on PTZ induced convulsion in mice

\begin{tabular}{lllll}
\hline Groups & Onset (s) & Straub's tail (s) & Convulsion (s) & Recovery (s) \\
\hline Control (0.1\% Sodium CMC) & $212.16 \pm 8.63$ & $114.83 \pm 8.93$ & $55.66 \pm 2.53$ & $926 \pm 49.62$ \\
Standard (diazepam (5 mg/kg) + PTZ & Absent & - & - & - \\
$100 \mathrm{mg} / \mathrm{kg}+$ PTZ & $234.16 \pm 11.05$ & $58.66 \pm 25.46^{\mathrm{c}}$ & $23 \pm 4.12^{\mathrm{a}}$ & $852.5 \pm 51.42$ \\
$200 \mathrm{mg} / \mathrm{kg}+$ PTZ & $237.33 \pm 5.47$ & $24.66 \pm 8.74^{\mathrm{b}}$ & $19.16 \pm 2.66^{\mathrm{a}}$ & $522.66 \pm 28.90^{\mathrm{a}, \mathrm{i}}$ \\
$400 \mathrm{mg} / \mathrm{kg}+$ PTZ & $280.16 \pm 9.81^{\mathrm{a}, \mathrm{e}, \mathrm{h}}$ & $1.5 \pm 0.50^{\mathrm{a}, \mathrm{f}}$ & $2.3 \pm 0.21^{\mathrm{a}, \mathrm{d}, \mathrm{g}}$ & $377.33 \pm 19.88^{\mathrm{a}, \mathrm{d}}$ \\
\hline
\end{tabular}

PTZ pentylenetetrazole

Values are expressed as Mean $\pm \mathrm{SEM} ; n=6$. One-way analysis of variance (ANOVA): $p$ value found to be $<0.0001$, considered extremely significant. Tukey-Kramer multiple comparisons test

${ }^{a} p<0.001$ in comparison with control

${ }^{\mathrm{b}} p<0.01$ in comparison with control

${ }^{c} p<0.05$ in comparison with control

${ }^{\mathrm{d}} p<0.001$ in comparison with low dose

e $p<0.01$ in comparison with low dose

${ }^{f} p<0.05$ in comparison with low dose

${ }^{9} p<0.01$ in comparison with medium dose

${ }^{\mathrm{h}} p<0.05$ in comparison with medium dose

${ }^{\mathrm{i}} p<0.001$ in comparison with low dose

of this tolerated dose $(2000 \mathrm{mg} / \mathrm{kg}$ ) were consequently selected for anticonvulsant activity assessment.

\section{Anticonvulsant activity study}

PTZ-administered mice exhibited straub's tail, tonicclonic convulsion, while pretreatment with diazepam totally eliminated these episodes of seizures. A. reticulata root ethanol extract $(100,200$ and $400 \mathrm{mg} / \mathrm{kg})$ treatment prolonged the onset of PTZ-induced tonic-clonic convulsion, reduced duration of straub's tail, convulsion and recovery. These effects were found to be dose-dependent when compared to control group animals. An exceptional inhibition of PTZ-induced convulsion was noticed in the animals administered with high dose of $400 \mathrm{mg} /$ $\mathrm{kg}$. Also, a significant reduction in duration of straub's tail, and recovery compared to mice received PTZ alone was detected in this high-dose-treated animal group (Table 4).

\section{Discussion}

Macro- and microscopical studies of crude drugs help to evolve diagnostic characters for proper identification [30]. A. reticulata (Linn.) can be identified by its characteristic crown shape and aromatic fruits, while root can be recognized by its fibrous fracture, mild sweet taste and aromatic odour. Microscopically, presence of oil content, rhomboidal crystals; and starch grains in medullary ray and xylem parenchyma are considered to be of prime importance. These characters along with various other key elements observed in macerate and powdered drug will aid in establishing the diagnostic characters that facilitate the correct identification of species.
Phytochemical studies act as a prerequisite to establish biomarker compounds for the purpose of identification and to determine the quality of plant materials [31]. Moisture, even though an inevitable component in plant materials, should be as low as possible in the crude drugs. Ash values provide knowledge on purity, quality, care taken to prepare the drug, while extractive values signifies the amount of constituents present in the drug material [30]. These physico-chemical parameters reported for the root material may be used to establish standardization parameters. Moreover, fluorescence analysis revealed various colour exhibited by powder under different wavelengths upon treatment with various reagents and these features will enable to, identify the drug in its powder form and differentiate from other powders also.

Acute toxicity study provides adequate information on toxicological properties of the administered substance through a single or short-term exposure in an organism [32]. No toxic signs and/or mortality were observed in acute toxicity study performed at an oral dose of $2000 \mathrm{mg} / \mathrm{kg}$ during the observational period of $24 \mathrm{~h}$. As there were no untoward effects with this single dose, it is suggestive of that the medium lethal dose $\left(\mathrm{LD}_{50}\right)$ is higher than $2000 \mathrm{mg} / \mathrm{kg}$ in mice. Considering this, three doses $100 \mathrm{mg} / \mathrm{kg}$ (low dose), $200 \mathrm{mg} / \mathrm{kg}$ (mid dose) and $400 \mathrm{mg} /$ $\mathrm{kg}$ (high dose) were selected for anticonvulsant activity.

The ethanol root extract was evaluated against convulsions induced by PTZ in Swiss Albino mice. PTZ, a potent GABA receptor antagonist inhibits GABA at $\mathrm{GABA}_{\mathrm{A}}$ receptors resulting in continuous stimulation of cortical neurons consecutively causing seizures that resemble Petit mal in humans [33, 34]. Thus, substances 
capable of augmenting GABA can prevent convulsion caused by PTZ [35]. Pretreatment with standard drug diazepam, a benzodiazepine derivative entirely abolished convulsions in mice. Ethanolic extract of $A$. reticulata root disclosed significant protection, and almost a complete abolition was observed in $400 \mathrm{mg} / \mathrm{kg}$ treated mice against PTZ-induced convulsion.

Important bioactives such as alkaloids, flavonoids, phenolic compounds and tannins and glycosides were found to be present in the root extracts. The protective role of these bioactive types [36-38] in PTZ-induced convulsions is described earlier; for instance, there are reports on flavonoids binding to $\mathrm{GABA}_{\mathrm{A}}$ receptor causing anticonvulsant effects [39]. Additionally, flavonoids also possess antioxidant property and can protect brain from oxidative damage [39]. Perhaps, the phytometabolites in $A$. reticulata root extract would have induced the inhibitory neurotransmitter (GABA) and/or, decreased the excitatory neurotransmission and/or blocked the sodium channels and/or neutralized the PTZ binding site [40]. Further studies are in place to derive the compound/s responsible for this persuasive activity and to elucidate their mechanism of action.

\section{Conclusions}

The macro-, microscopical studies and preliminary phytochemical analysis of $A$. reticulata root have been carried out, besides anticonvulsant screening of ethanol extract against PTZ-induced convulsion. The diagnostic characters and physico-chemical constants discussed may be of potential application in the identification of the root material, and also to establish standardization parameters. An effective anticonvulsant activity of root extract is further needed to be explored for the accountable bioactive constituents.

\section{Abbreviations}

CPCSEA: Committee for the Purpose of Control and Supervision of Experiments on Animals; CK: cork; CTX: cortex; SPH: secondary phloem; MR: medulary ray; SXY: secondary xylem; OG: oil globule; SC: sclerenchyma cell; V: vessel; SG: starch grain; CR: crystal.

\section{Acknowledgements}

The authors are thankful to Dr. V. Madhavan, HoD, Department of Pharmacognsoy, and Dr. J Anbu, Professor, Department of Pharmacology, Faculty of Pharmacy, MSRUAS, for their support throughout the work.

\section{Study involving plants}

The plant material was authenticated by Dr. A. N. Sringeswara, Curator, Mahatma Gandhi Botanical Garden, UAS, GKVK, Bangalore.

\section{Authors' contributions}

KSS and MA designed and supervised the work. MKS performed the study and collected the data. Data were interpreted by MKS, KSS and MA. All the authors contributed to the preparation of the manuscript. All authors read and approved the final manuscript.
Funding

No funding was received.

Availability of data and material

Data and material are available upon request.

\section{Declarations}

Ethics approval and consent to participate

The animals for this study were obtained from the animal house, Department of Pharmacology, Faculty of Pharmacy, and the study protocol was approved by the Institutional Animal Ethical Committee (IAEC), MSRUAS ((XXII/MSRFPH/ COG/M-027).

\section{Consent for publication}

Not applicable.

\section{Competing interests}

The authors declare no conflicts of interest.

\section{Author details}

${ }^{1}$ Department of Pharmacognosy, Faculty of Pharmacy, M. S. Ramaiah University of Applied Sciences, Bangalore, Karnataka 560 054, India. ${ }^{2}$ Department of Pharmacology, Faculty of Pharmacy, M. S. Ramaiah University of Applied Sciences, Bangalore, Karnataka 560 054, India.

Received: 15 March 2021 Accepted: 8 August 2021

Published online: 28 August 2021

\section{References}

1. Trinka E, Cock H, Hesdorffer D, Rossetti AO, Scheffer IE, Shinnar S, Shorvon S, Lowenstein DH (2015) A definition and classification of status epilepticus-report of the ILAE task force on classification of status epilepticus. Epilepsia 56(10):1515-1523. https://doi.org/10.1111/epi.13121

2. Goldenberg MM (2010) Overview of drugs used for epilepsy and seizures: etiology, diagnosis, and treatment. PT Peer-Rev J Formul Manag 35(7):392-415

3. Aneja S, Sharma S (2013) Newer anti-epileptic drugs. Indian Pediatr 50(11):1033-1040. https://doi.org/10.1007/s13312-013-0284-9

4. Tandon N, Yadav SS (2017) Contributions of Indian Council of Medical Research (ICMR) in the area of Medicinal plants/traditional medicine. J Ethnopharmacol 197:39-45. https://doi.org/10.1016/j.jep.2016.07.064

5. Amjad MS, Zahoor U, Bussmann RW, Altaf M, Gardazi SMH, Abbasi AM (2020) Ethnobotanical survey of the medicinal flora of Harighal, Azad Jammu \& Kashmir, Pakistan. J Ethnobiol Ethnomed 16:65. https://doi.org/ 10.1186/s13002-020-00417-w

6. Gamble JS (2005) The flora of the presidency of Madras, vol 1. Bishen Singh Mahendra Pal Singh, Dehradun, pp 10-24

7. Attiq A, Jalil J, Husain K (2017) Annonaceae: breaking the wall of inflammation. Front Pharmacol 8:752. https://doi.org/10.3389/fphar.2017.00752

8. Eva González-Trujano M, Tapia E, López-Meraz L, Navarrete A, ReyesRamírez A, Martínez A (2006) Anticonvulsant effect of Annona diversifolia Saff. and palmitone on penicillin-induced convulsive activity. A behavioral and EEG study in rats. Epilepsia 47(11):1810-1817. https://doi.org/10. 1111/j.1528-1167.2006.00827.x

9. Amudha P, Varadharaj V (2017) Phytochemical and pharmacological potential of Annona species: a review. Asian J Pharm Clin Res 10(7):68-75. https://doi.org/10.22159/ajpcr.2017.v10i7.18073

10. Jamkhande PG, Wattamwar AS (2015) Annona reticulata Linn. (Bullock's heart): plant profile, phytochemistry and pharmacological properties. J Tradit Complement Med 5(3):144-152. https://doi.org/10.1016/j.jtcme. 2015.04 .001

11. Yoganarasimhan SN (2000) Medicinal plants of India, vol 2. Cyber Media, Bangalore, $\mathrm{p} 48$

12. Chavan SS, Shamkuwar PB, Damale MG, Pawar DP (2014) A comprehensive review on Annona reticulata. IJPSR 5(1):45-50. https://doi.org/10. 13040/IJPSR.0975-8232.5(1).45-50 
13. Suresh HM, Shivakumar B, Hemalatha K, Heroor SS, Hugar DS, Rao KR (2011) In vitro antiproliferative activity of Annona reticulata roots on human cancer cell lines. Pharmacogn Res 3(1):9-12. https://doi.org/10. 4103/0974-8490.79109

14. Suresh HM, Shivakumar B, Shivakumar SI (2012) Cytotoxicity of aporphine alkaloids from the roots of Annona reticulata on human cancer cell lines. Int J Plant Res 2(3):57-60. https://doi.org/10.5923/j.plant.20120203.02

15. Jamkhande PG, Wattamwar AS, Pekamwar SS, Chandak PG (2014) Antioxidant, antimicrobial activity and in silico PASS prediction of Annona reticulata Linn. root extract. Beni-Suef Univ J Basic Appl Sci 3(2):140-148. https://doi.org/10.1016/j.bjbas.2014.05.008

16. Jamkhande PG, Wattamwar AS, Chandak PG (2014) In vitro anthelmintic efficacy of ethno-medicinal plant Annona reticulata L. roots against Indian earthworms (Pheretimaposthuma). Indian J Nat Prod Resour 5(2):152-157

17. Yamthe LRT, Fokou PVT, Mbouna CDJ, Keumoe R, Ndjakou BL, Djouonzo PT, Mfopa AN, Legac J, Tsabang N, Gut J, Rosenthal PJ, Boyom FF (2015) Extracts from Annona muricata L. and Annona reticulata L. (Annonaceae) potently and selectively inhibit Plasmodium falciparum. Medicines 2(2):55-66. https://doi.org/10.3390/medicines2020055

18. Mallick S, Chandra G (2015) Larvicidal potentiality of root extracts of Annona reticulata Linn. against the filarial vector Culex quinquefasciatus Say (Diptera: Culicidae). J Mosq Res 5(10):1-7. https://doi.org/10.5376/jmr. 2015.05.0010

19. Jain SK, Rao RR (1977) A handbook of field and herbarium methods. Today and Tomorrow Printers and Publishers, New Delhi, pp 22-61

20. Wallis TE (1985) Text book of pharmacognosy, 5th edn. CBS Publishers and Distributors, New Delhi, pp 352-358

21. Evans WC (2002) Trease and evans pharmacognosy, 16th edn. Saunders, London, pp 537-570

22. Anonymous (1996) Indian pharmacopoeia. The Controller of Publications, New Delhi, pp A53-55

23. Kokoski CJ, Kokoski RJ, Slama FJ (1958) Fluorescence of powdered vegetable drugs under ultra violet radiation. J Am Pharm Assoc 47(10):715-717. https://doi.org/10.1002/jps.3030471010

24. Kokate CK, Purohit AP, Gokhale SB (2017) Pharmacognosy, 53rd edn. Nirali Prakashan, Pune, pp 7.15-7.19

25. Rinaldi MVN, Díaz IEC, Suffredini IB, Moreno PRH (2017) Alkaloids and biological activity of beribá (Annona hypoglauca). Rev Bras Farmacogn 27:77-83. https://doi.org/10.1016/j.bjp.2016.08.006

26. Kamtekar S, Keer V, Patil V (2014) Estimation of phenolic content, flavonoid content, antioxidant and alpha amylase inhibitory activity of marketed polyherbal formulation. J Appl Pharm Sci 4(9):61-65. https:// doi.org/10.7324/JAPS.2014.40911

27. Organization for Economic Co-operation and Development (OECD) Guideline No. 423. Acute oral toxicity in animals. OECD/OCDE No. 423, adopted 17th Dec, 2001.

28. Saikia A, Purkayastha A, Tigga R, Roy D (2016) Anticonvulsant activity of the methanolic extract of Lawsonia inermis leaves in albino rats. Int J Pharm Sci Res 7(7):3068-3072. https://doi.org/10.13040/IJPSR.0975-8232. 7(7).3068-72
29. Bhosle V (2013) Anticonvulsant and antioxidant activity of aqueous leaves extract of Desmodium triflorum in mice against pentylenetetrazole and maximal electroshock induced convulsion. Rev Bras Farmacogn 23(4):692-698. https://doi.org/10.1590/S0102-695X2013005000047

30. Chanda S (2014) Importance of pharmacognostic study of medicinal plants: an overview. J Pharmacogn Phytochem 2:69-73

31. Namrta C, Siddiqui MB, Sayyada K (2014) Pharmacognostic evaluation of Tinospora cordifolia (Willd.) Miers and identification of biomarkers. Indian J Tradit Knowl 13(3):543-550

32. Fauci AS et al (2008) Harrison's principles of internal medicine, 17th edn. McGraw-Hill Professional, New York, pp 189-195

33. Psarropoulou C, Matsokis N, Angelatou F, Kostopoulos G (1994) Pentylenetetrazol-induced seizures decrease gamma-aminobutyric acid-mediated recurrent inhibition and enhance adenosine-mediated depression. Epilepsia 35(1):12-19. https://doi.org/10.1111/j.1528-1157.1994.tb02906.x

34. Huang RQ, Bell-Horner CL, Dibas MI, Covey DF, Drewe JA, Dillon GH (2001) Pentylenetetrazole-induced inhibition of recombinant gamma-aminobutyric acid type $A(G A B A(A))$ receptors: mechanism and site of action. J Pharmacol Exp Ther 298(3):986-995

35. Fisher RS, van Emde BW, Blume W, Elger C, Genton P, Lee P, Engel J Jr (2005) Epileptic seizures and epilepsy: definitions proposed by the International League Against Epilepsy (ILAE) and the International Bureau for Epilepsy (IBE). Epilepsia 46(4):470-472. https://doi.org/10.1111/j.00139580.2005.66104.x

36. Bukhari IA, Pivac N, Alhumayyd MS, Mahesar AL, Gilani AH (2013) The analgesic and anticonvulsant effects of piperine in mice. J Physiol Pharmacol 64(6):789-794

37. Danjuma NM, Chindo BA, Abdu-Aguye I, Anuka JA, Hussaini IM (2014) Psychopharmacological properties of saponins from Randia nilotica stem bark. Pharm Biol 52(1):1-7. https://doi.org/10.3109/13880209.2013. 784343

38. Varma GG, Mathai BK, Das K, Gowda G, Rammohan S, Einstein JW (2014) Evaluation of antiepileptic activity of methanolic leaves extract of Tragiain volucrata Linn. in mice. Int Lett Nat Sci 17:167-179. https://doi.org/10. 18052/www.scipress.com/ILNS.17.167

39. Diniz TC, Silva JC, de Lima-Saraiva SR, Ribeiro FP, Pacheco AG, de Freitas RM, Quintans-Júnior LJ, Quintans J, Mendes RL, Almeida JR (2015) The role of flavonoids on oxidative stress in epilepsy. Oxid Med Cell Longev. https://doi.org/10.1155/2015/171756

40. Nkamguie Nkantchoua GC, Kameni Njapdounke JS, Jules Fifen J, Sotoing Taiwe G, Josiane Ojong L, Kavaye Kandeda A, Ngo Bum E (2018) Anticonvulsant effects of Senna spectabilis on seizures induced by chemicals and maximal electroshock. J Ethnopharmacol 212:18-28. https://doi.org/10. 1016/j.jep.2017.09.042

\section{Publisher's Note}

Springer Nature remains neutral with regard to jurisdictional claims in published maps and institutional affiliations. 